\title{
Farmers' sustainable agriculture perception in Turkey: The case of Mersin province
}

\author{
Seyit Hayran ${ }^{\star}$, Aykut Gul ${ }^{\star}$, Mehmet Ali Saridas ${ }^{\star *}$
}

DOI: $10.30682 / \mathrm{nm} 1803 \mathrm{f}$

Jel codes: Q01, Q10

\begin{abstract}
The main purpose of this study was to measure farmers' sustainable agriculture perception and its determinants in Turkey based on a case study in Mersin Province. The data were collected from randomly selected 239 farmers in June 2017. The data set were gathered by using a structured questionnaire with Cronbach's alpha coefficient of 0.946. According to the result, farmers had favorable perception in issues related to sustainable agricultural practices such as protection of agricultural resources, negative effects of agrochemicals on human health and the environment, input application, crop rotation, minimum tillage etc. In addition, the study revealed that agricultural programs on TV and radio, credit use and cooperative partnership were factors that affected farmers' sustainable agriculture perceptions. The study investigated farmers' sustainable agriculture perception, not predict whether farmers will adopt sustainable agriculture practices or whether they did them. Hence, it is necessary that further research should be conducted to find out whether farmers are likely to do so or whether really they did them.
\end{abstract}

Keywords: Perception, Sustainable agriculture, Turkey.

\section{Introduction}

A negative impact of economic development on the environment has been discussed since the 1980s. In 1987, the concept of "Sustainable Development" was introduced with the report "Our Common Future" in order to overcome these negative impacts (Brundtland and Khalid, 1987). Parallel to these developments, the negative effects of intensive agriculture on the environment and human health have also been the subject of debate, and as a result of the debates, the concept of "sustainable agriculture" has come to the fore in the 1990s. Sustainable agriculture is the approach that necessary to be provided some conditions at the same time; (1) makes better use of natural goods and services for meet present generations' needs without compromising the ability of future generations to meet their own needs; (2) without damaging the environment (3) minimizes the use of external inputs and (4) to ensure the balance between social, natural and economic needs (Turhan, 2005; Zhen et al., 2005). For this purpose, sustainable agriculture uses methods that do not create negative externalities such as crop rotation and diversification, soil improver ap-

\footnotetext{
* University of Cukurova, Department of Agricultural Economics, Adana, Turkey.

** University of Cukurova, Department of Horticulture, Adana, Turkey.

Corresponding author: shayran@cu.edu.tr.
} 
plications, biological control, integrated pest management, etc. (Adeola and Adetunbi, 2015; Terano et al., 2013; Thanh et al., 2015; Turhan, 2005; Zhen et al., 2005).

To ensure ecological, economic and social sustainability, farmers must adopt different farm-level technologies such above. In order to farmers to be persuaded to adopt and implement sustainable agricultural technologies, they first need to believe that these technologies are vital for to meet the needs of both present and future generations, provide protective for the rural environment and create stable and longterm income (Tatlidil et al., 2009; Thanh et al., 2015). Moreover, some studies results show that the perceived importance of agricultural sustainability differs from farmer to farmer and it is influenced by their socio-economic characteristics and information-seeking behaviour (Bagheri, 2010; Bagheri et al., 2008; Tatlidil et al., 2009; Thanh et al., 2015). Hence, investigating farmers' perceptions about sustainable agriculture and examining the factors influencing those perceptions is crucial to design extension programs for sustainable agricultural development and to secure our common future (Tatlidil et al., 2009).

There have been conducted various survey studies which consist of different indicators designed to examine farmers' perception toward sustainable agriculture. Bagheri (2010) developed a scale consist of 12 items in order to analysis potato farmers' attitude towards sustainable agriculture in terms of resource conservation, negative effects of agrochemicals, pest invasion arising from successive cultivation models and problems of human and animal health. He also reported that sample farmers had favorable attitude towards sustainable practices such as resource conservation, negative effects of agrochemicals, pests' invasion arising from successive cultivation. Those were emphasized that there were moderate attitude towards the negative environmental effects of modern agricultural technologies and regarding negative long-term effects of agrochemicals on agricultural productivity and low tillage respondents had negative perception in the same study. Beside these results, Baghari (2010) stated that there was a relationship between a numbers of socio-economic factors, such as education, information sources use, extension participation and the farmers' sustainable agriculture perception. Migliorini and Scaltriti (2012) estimating the agro-environmental sustainability of three farming systems through indicators related to the soil, water, air and landscape-biodiversity. They reported that the analyzed farms are managed in a barely sustainable with regard to economic aspects, but have quite a negative impact on the environment. Tatlidil et al., (2009) developed 21 different sustainability indicators related to animal health, marketing, farms management and resource use. According to their results, farmers had medium level perception towards sustainable agriculture in Kahramanmaras Province of Turkey. They reported that, farmers, especially, had very high perception towards «leaving the farm to one heir only», «long-term crop rotation» and «not burning residues after harvest» and they also stated that farmers had low perceptions towards «proper use of energy sources in agriculture», «growing cover crops» and «conducting soil test» indicators. Beside this, they reported that the higher the socio-economic status (more frequent contact with extension services, higher education, ownership of land, etc.) and the greater the access to information, the greater the perceived importance of sustainable agricultural practices. Adeola and Adetunbi, (2015) conducted their study in order to examined the perception of farmers with respect to sustainable agriculture that produces abundant food devoid of the earth's resources depletion in three states (Oyo, Osun and Ekiti) of the south-west, Nigeria. According to their findings, farmers were favorably disposed to the practice of sustainable agriculture and realized its potentials as an alternative to industrial agriculture, a profitable venture, capable of providing a healthy family income that would improve the rural economy. According to research findings, they suggested that extension agency should intensify efforts through collaboration with relevant non-governmental organizations to disseminate appropriate information on sustainable agriculture practices and benefits. In addition to the these 
studies, some other studies have been conducted to investigate farmers' perceptions of sustainability (Shakiru, 2016; Shiri et al., 2013; Terano et al., 2013; Thanh et al., 2015). As outlined above, despite there was a wide literature about farmers' sustainable agriculture perception, there was only one study in Turkey (Tatlidil et al., 2009). This study has attempted to fill the gap a little bit in Turkey.

The main purpose of this study was to investigate farmers' sustainable agriculture perception in Mersin Province. Within this general purpose framework, the present study was conducted on sample farmers with following specific objectives:

- to describe farmers' socio-economic characteristics and information-seeking behavior,

- to measure farmers' sustainable agriculture perception,

- to determine the selected socio-economic characteristics and information-seeking behavior that influence farmers' sustainable agriculture perception.

\section{Materials and Methods}

Mersin province is located in Mediterranean Region of Republic of Turkey and its western neighbour is Antalya, eastern neighbour is Adana, northern neighbours are Nigde, Konya and Karaman and it is surrounded with Mediterranean Sea on the south. The north-south borders of the province are between $36-37^{\circ}$ Northern latitudes and the east-west borders are between 33$35^{\circ}$ Eastern longitudes. The territorial border of the province is $608 \mathrm{~km}$ and coastal border is 321 $\mathrm{km}$, and the area it covers is $15.953 \mathrm{~km}^{2}$. Mersin province counts for $2 \%$ of the surface area of Turkey. Mersin has 13 districts. The climatic conditions are under the impact of the Mediterranean. More than half of the annual precipitation takes place in autumn and winter months. Snow fall does not take place in the low altitude regions, yet it approaches in plateaus and high altitude regions. The annual amount of precipitation is $450-736 \mathrm{~mm}$, and there are significant differences in low altitude regions. The average temperature of the province is $7.5^{\circ} \mathrm{C}$ in February and $26^{\circ} \mathrm{C}$ in July. Mersin province is subdivid- ed into four agro-ecological sub-regions due to biophysical significance and socio-economical level of development (Anonymous, 2011; Anonymous, 2015).

The data set used in this study was collected from farmers in Mersin province. A cross sectional survey method was used in this study during the period of June 2017 in 9 districts of Mersin. 239 randomly selected farmers were visited to obtain data. The instrument for data collection was a structured questionnaire that consists of two sections. The first section consisted of information on socio-economic characteristics and information-seeking behavior of farmers. The second section was a list of 19 items designed to assess the farmers' sustainable agriculture perception. These were prepared taking into account the previous studies about sustainability (Adeola and Adetunbi, 2015; Bagheri, 2010; Bagheri et al., 2008; Ceyhan, 2010; Sadati et al., 2010; Shiri et al., 2013; Tatlidil et al., 2009; Terano et al., 2013; Thanh et al., 2015) and the socio-economic, political, and environmental conditions of agriculture in the region (Anonymous, 2011; Anonymous, 2015). Questionnaire reliability was estimated by calculating Cronbach's alpha coefficient (Cronbach, 1951) which was 0.946 for the scale of perception.

Descriptive statistics such as the mean and standard deviation were used in order to delineate farmers' socio-economics characteristics and information-seeking behaviours (Kalayc1, 2008; Unver and Gamgam, 2008). In order to analysis farmers' sustainable agriculture perception, they were asked to indicate the degree of their agreement on each items using a Likert-type fivepoint continuum scale of Entirely Agree, Agree, Moderate Agree, Disagree and Entirely Disagree with appointing a weight of 5, 4, 3, 2 and 1 for all items.

The mean for all items were categorized as follows:

Entirely Disagree $(E D)=1.00-1.49$,

Disagree $(\mathrm{DI})=1.50-2.49$,

Moderate Agree $(\mathrm{MA})=2.50-3.49$,

Agree $(\mathrm{AG})=3.50-4.49$,

Entirely Agree $=(\mathrm{EA})=4.50-5.00$. 
The sustainable agriculture perception level of farmers was classified using the interval standard deviation from mean as follows:

$$
\begin{aligned}
& \text { A }=\text { Low: } A \leq \text { Mean }-2 \text { SD, } \\
& \mathrm{B}=\text { Moderate: Mean }-2 \mathrm{SD}<\mathrm{B}<\text { Mean, } \\
& \mathrm{C}=\text { High: } \mathrm{C} \geq \text { Mean }
\end{aligned}
$$

In this study, stepwise regression analysis was used in order to determine the selected variables influencing the farmers' sustainable agriculture perception (Hair et al., 1994). The model used in this study was presented below.

$$
Y_{i}=\beta_{1}+\beta_{2} X_{2}+\beta_{3} X_{3}+\ldots+\beta_{n} X_{n}+e_{i}
$$

In equation,

$Y_{i}$ was $i$-th farmer's the total value for general sustainable agriculture perception for the scale it ranged from 19 to 95 .

$\beta_{1}-\beta_{n}$ were coefficient of constant term and coefficients of independent variables.

$X_{2}-X_{n}$ were independent variables which presented in Table 1.

$e_{i}$ was error term.

The mean values and standard deviations of the variables were summarized in the "Farmers' socio-economic characteristics" and "Farmers' information-seeking behavior" sections. All statistical analyzes were performed using IBM SPSS Statistics 21.

\section{Results and Discussion}

All of the sample farmers were male; their age ranged from 18 to 81 and the mean age was 47.77 years (SD:13.35). Farmers' education was mid-level; on average, the number of years in school of farmers was 7.85 years (SD:3.40). The mean household size was 4.25 members (SD:1.50). $31.40 \%(n=75)$ of the farmers used credit for inputs and $22.60 \%(n=54)$ of them had agricultural insurance. $27.20 \%$ of farmers were cooperative partners. The mean farm size was 3.59 ha and the numbers of plots were 3.52 on average.

Except for access to agricultural programs on

\begin{tabular}{|c|c|}
\hline Variables & Definition and Measurement \\
\hline \multicolumn{2}{|c|}{ Dependent variable } \\
\hline $\begin{array}{l}\text { Farmers' } \\
\text { perception }\end{array}$ & $\begin{array}{l}\text { Farmer's the total value for } \\
\text { general sustainable agriculture } \\
\text { perception (Score) }\end{array}$ \\
\hline \multicolumn{2}{|c|}{ Independent variables } \\
\hline Age & Farmers' age (In year) \\
\hline Education & $\begin{array}{l}\text { Farmers' education (Year of } \\
\text { schooling) }\end{array}$ \\
\hline Family size & $\begin{array}{l}\text { Total number of family } \\
\text { members (Number) }\end{array}$ \\
\hline $\begin{array}{l}\text { Total } \\
\text { landholding }\end{array}$ & Landholding size (In decares) \\
\hline Parcel & Total parcel number (Number) \\
\hline Credit Use & $\begin{array}{l}\text { Credit use for inputs } \\
\text { (credit use }=1 ; 0 \text { otherwise) }\end{array}$ \\
\hline Insurance & $\begin{array}{l}\text { Purchase agricultural insurance } \\
\text { in last production year } \\
\text { (yes }=1 ; 0 \text { otherwise) }\end{array}$ \\
\hline $\begin{array}{l}\text { Cooperative } \\
\text { Partnership }\end{array}$ & $\begin{array}{l}\text { Cooperative partnership } \\
\text { (yes }=1 ; 0 \text { otherwise) }\end{array}$ \\
\hline Extension & $\begin{array}{l}\text { Extension contact ( } 1 \text { yes, } \\
0 \text { otherwise) }\end{array}$ \\
\hline Printed material & $\begin{array}{l}\text { Reading the printed material } \\
\text { like agricultural book, } \\
\text { brochure etc. in the last month } \\
\text { (1 yes, } 0 \text { otherwise) }\end{array}$ \\
\hline Computer & $\begin{array}{l}\text { Computer ownership (1 yes, } \\
0 \text { otherwise) }\end{array}$ \\
\hline $\begin{array}{l}\text { Agricultural } \\
\text { programs on } \mathrm{TV}\end{array}$ & $\begin{array}{l}\text { Watching agricultural } \\
\text { programs on TV in last one } \\
\text { month (yes }=1 ; 0 \text { otherwise) }\end{array}$ \\
\hline $\begin{array}{l}\text { Agricultural } \\
\text { programs on } \\
\text { Radio }\end{array}$ & $\begin{array}{l}\text { Listening to agricultural } \\
\text { programs on radio in last one } \\
\text { month (yes }=1 ; 0 \text { otherwise) }\end{array}$ \\
\hline $\begin{array}{l}\text { Agricultural } \\
\text { training }\end{array}$ & $\begin{array}{l}\text { Agricultural training attended } \\
\text { by farmers in the last year } \\
\text { (Number) }\end{array}$ \\
\hline
\end{tabular}
$\mathrm{TV}$, farmers' access to agricultural information
Table 1 - Variables used in stepwise regression analysis.

from other media namely radio, agricultural extension program, newspapers, leaflet and books was mid-level. $62.30 \% \quad(n=149)$ of farmers watched agricultural programs on TV for at least one time in the past month. Only $31.10 \%$ 
$(\mathrm{n}=79)$ of farmers listened to agricultural programs on radio for at least one time in the past month. $10.00 \%(n=24)$ of farmers read agricultural, newspapers, leaflet and books at least one time in the past month. $18.43 \%$ of sample farmers participated in agricultural extension course at least one time in the past one year. $37.20 \%$ $(\mathrm{n}=89)$ of farmers had personal computer and only $10.00 \%(n=24)$ of them had private agricultural adviser.

\subsection{Farmers' sustainable agriculture percep- tion}

As shown in table 2, 5.86\% of the farmers $(\mathrm{n}=14)$ had low sustainable agriculture perception; whereas $67.36 \%$ of them $(n=161)$ had high perception, $26.78 \%(n=64)$ of farmers had moderate perception towards sustainable agriculture. Therefore, it can be stated that the majority of farmers $(94.14 \%$; $n=225)$ had favorable perception towards sustainable agriculture in Mersin.

Table 3 shows sample farmers attach how importance to each of selected sustainable agricultural indicators. Based on the interpretive scale described in data analysis section, 6 indicators were placed in the entirely agree (EA) category, 11 indicators in the agree (AG) category, 2 indicators in moderate agree (MA). No indicator was placed in the disagree category (DI) and entirely disagree (ED) category.

In terms of EA category, the study pointed out that sample farmers had highly positive perception about protecting natural resources for future generations. They participated at a very high level in the «even causes short-term losses, natural resources must be protected» indicator. Beside this, farmers had serious concern about issues of uncontrolled and indiscriminate uses of agrochemicals affecting both human health and environment and they believed that extreme and unconscious agrochemicals may lead to environmental pollution. And also they consider that sustainable agriculture prevents the polluting and destroying of natural resources. In fact, excessive and the indiscriminate use of agrochemicals lead to very important environmental problems such as soil salinity, heavy metal accumulation, water eutrophication, accumulation
Table 2 - Farmers' sustainable agriculture perception level.

\begin{tabular}{|l|c|c|}
\hline Perception Level & Frequency & $\%$ \\
\hline Low (A) & 14 & 5.86 \\
\hline Moderate (B) & 64 & 26.78 \\
\hline High (C) & 161 & 67.36 \\
\hline Total & 239 & 100.00 \\
\hline
\end{tabular}

of nitrate and air pollution in the air of gases containing nitrogen and sulfur (Savci, 2012). Considering Rahman and Debnath (2015), it can be said that «pesticides are applied over the vegetable which are directly entered into human or livestock bodies. Excessive use of fertilizers may pollute the underground water with nitrate and it is so much hazardous to humans or livestock. Nitrate concentrated water can immobilize some of hemoglobin in blood. Organophosphate pesticides have increased in application, because they are both less persistent and harmful for environment than organochlorine pesticides. But, they are associated with acute health problems, such as abdominal pain, dizziness, headaches, nausea, vomiting, as well as skin and eye problems». This result is supported by Thanh et al. (2015) who reported that banana farmers had a highly positive perception of protecting natural resources for their future generations and they also stated their serious concern about issues of uncontrolled agrochemical uses affecting human health. According to our results, the development of suitable economic measures and policies may prevent the use of excessive and unconscious agrochemicals in the research area. In order to overcome or reduce these problems, biological control is an alternative to agrochemicals. In research area, farmers rating for the «biological control is the best ways to control and reduce damage of pests and weeds» and «integrated pest management practices reduce the need for pesticides» indicators were high. This means that farmers may canalize to biological control and integrated pest management methods by using appropriate guidance and incentive tools.

Cover crop cultivation may be considered a new practice in Turkey. Some previous studies 
reported that cover crop cultivation have some benefits such as promoting pest-suppression, soil and water quality, nutrient cycling efficiency, cash crop productivity, reduce soil erosion $(\mathrm{Gu}$ and Anex, 2015; Snapp et al., 2005). Fortunately, farmer's rating for the «cover crop cultivation improves soil fertility and reducing erosion» indicator was high. This showed that the farmers had knowledge about the benefits of cover crops and had the potential for growing these crops in Mersin. Our finding is conflict with Tatlidil et al. (2009) who reported that farmers rating low importance to the cover crop cultivation in Kahramanmaras Province of Turkey.

Burning crop residues after the harvest is a important problem in rural areas of Turkey. Although it is forbidden by law (Turkish Civil Code, 1983), many farmers burn the residues in their fields because it is easier to do so. Some farmers believe that burning residues in fields require less cost. However, sustainable agriculture consider that burning residues is harmful: the fire kills many beneficial soil microorganisms, lowers organic matter, reduces soil infiltration capacity and yields, and promotes soil erosion (Kilic et al., 2012). Fortunately, farmers participated at a very high level in the "plant residues should not be burned after harvest» indicator and it was placed in the EA category. This finding is supported by Tatlidil et al. (2009). Both legal restrictions and awareness of the farmers may brake this harmful practice in the future.

Regarding the AG category, sample farmers had a positive perception about using good agricultural practice such as crop rotation, diversification, good soil preparation, application of organic fertilizer, minimum tillage, integrated pest management practices to maintain soil fertility, soil humidity, reduce erosion, manage insect pests and diseases and reduce the need for pesticide. As a result of this study, it can be said that sample farmers had a favorable perception toward benefits of good agricultural practice such as minimum tillage, crop rotation and diversification, integrated pest management and application of organic fertilizer.

In terms of AG category, the study pointed out that sample farmers had highly positive perception about «Soil tests should be conducted be- fore applying fertilizers» indicators. This finding showed that farmers believe it necessary to have their soils tests before applying fertilizer for determining the quantity and quality of the nutrients contained in the soil. This finding is not consistent with Tatlidil et al. (2009) who reported that the farmers may regard any new practice as risky and less productive; also, their attitudes and beliefs make it difficult for them to adopt new ideas in Turkey. But over the last decade, soil tests have been sufficiently well-known in Turkey. The soil test to be done before fertilizing has both ecological and economical benefits. Soil test results provide farmers with appropriate fertilizer application recommendations for plant nutritions. If farmers apply too little fertilizer, their yields and returns will be lower. Too much fertilizer lead to economic loss and environmental pollution risks (NCRS, 2014). Tanriverdi (2017) reported that the farms that had soil test before fertilizer had higher gross profits per decares than whose did not. Therefore, soil tests are vital for farm survival.

Farmers participated at a high level in the «crop rotation improves soil fertility and reduces soil erosion», «crop rotation and diversification reduce pests and diseases» and «minimum tillage can reduce erosion and soil degradation» indicators. In fact, these practices may improve soil quality, reduce soil erosion and reduce pests and diseases. According to Abdullah (2014), practicing minimum tillage is an effective solution to improve soil quality and agricultural productivity in the semiarid areas. Preiti et al. (2017) reported that appropriate tillage system and crop rotation may reduce soil erosion risk. Considering Guo et al. (2005), an appropriate crop rotation and tillage strategy could be effective in reducing canola diseases. According to the result of Acar et al. (2018), conservation tillage systems could be useful to carbon sequestration and reduce soil erosion together with the crop residues on the soil surface in a high clay content soil under Mediterranean climatic conditions.

Farmers also perceived that sustainable agriculture can be a solution of the problems of polluting and destroying of natural resources, increase profits and reduces production risks in the 
Table 3 - Farmers' sustainable agriculture perception.

\begin{tabular}{|c|l|c|c|c|}
\hline Rank & Indicators of Sustainable Agriculture & Mean & S.D. & Category \\
\hline I-1 & Natural resources must be protected for future generations & 4.66 & 0.77 & EA \\
\hline I-2 & Environmental pollution can be caused by agrochemicals & 4.62 & 0.75 & EA \\
\hline I-3 & $\begin{array}{l}\text { The indiscriminate uses of agrochemicals are harmful for human } \\
\text { health }\end{array}$ & 4.59 & 0.82 & EA \\
\hline I-4 & Cover crop cultivation improves soil fertility and reduces erosion & 4.54 & 0.79 & EA \\
\hline I-5 & Plant residues should not be burned after harvest & 4.54 & 0.86 & EA \\
\hline I-6 & Even causes short-term losses, natural resources must be protected & 4.50 & 0.82 & EA \\
\hline I-7 & Soil tests should be conducted before applying fertilizers & 4.49 & 0.83 & AG \\
\hline I-8 & Crop rotation improves soil fertility and reduces soil erosion & 4.46 & 0.85 & AG \\
\hline I-9 & $\begin{array}{l}\text { Application of organic fertilizers and mulches can increase soil } \\
\text { fertility and maintain soil humidity }\end{array}$ & 4.46 & 0.83 & AG \\
\hline I-10 & Good soil preparation and sowing limits weeds and gets high yields & 4.44 & 0.83 & AG \\
\hline I-11 & $\begin{array}{l}\text { Biological control is the best way to control and reduce damage } \\
\text { of pests and weeds }\end{array}$ & 4.38 & 0.93 & AG \\
\hline I-12 & $\begin{array}{l}\text { Sustainable agriculture can increase profits and reduces production } \\
\text { risks in the long-term }\end{array}$ & 4.38 & 0.92 & AG \\
\hline I-13 & Crop rotation and diversification reduce pests and diseases & 4.37 & 0.93 & AG \\
\hline I-14 & $\begin{array}{l}\text { Sustainable agriculture prevents the polluting and destroying } \\
\text { of natural resources }\end{array}$ & 4.37 & 0.96 & AG \\
\hline I-15 & Minimum tillage can reduce erosion and soil degradation & 4.37 & 0.99 & AG \\
\hline I-16 & Integrated pest management practices reduce the need for pesticides & 4.36 & 0.99 & AG \\
\hline I-17 & $\begin{array}{l}\text { Contract farming maintains the stability of product prices and } \\
\text { farming income }\end{array}$ & 4.30 & 1.03 & AG \\
\hline I-18 & $\begin{array}{l}\text { Land fragmentation must be prevented and leaves farmland to only } \\
\text { one heir }\end{array}$ & 3.31 & 1.48 & MA \\
\hline I-19 & Indigenous knowledge is fit for sustainable agriculture & 3.20 & 1.15 & MA \\
\hline & Total & 4.33 & 0.67 & \\
\hline
\end{tabular}

long-term. This finding consistent that of Thanh et al. (2015). Our study showed that farmers aware about the importance of contract farming. Farmers regarded it as a good way to maintain the stability of product prices and farming income. In fact, production through contracts is an increasing trend in agriculture that can help farmers to gain more profits in Turkey (Ozcelik et al., 1999).

One of the most important problems about sustainable use of agricultural land in Turkey is land fragmentation (Ministry of Development, 2014). Land consolidation is being carried out in Turkey in order to eliminate fragmentation of land. There are also some laws for preventing the re-fragmentation of the land. According to Law No. 5578, the size of the agricultural land parcel with the smallest area where agricultural activity can be done economically will be determined by considering the social, economic, ecological and technical characteristics of the regions. Then, Law No. 5578 stipulates that agricultural land can not divide under the determined size. Fortunately, «Land fragmentation must be prevented and leaves farmland to only one heir» was considered important practice related to sustainable agriculture in Mersin. Sample farmers had moderate perception mean score on it and it was 
placed in MA category. Considering this result, it can be said that farmers adopt this law. This result is supported by Tatlidil et al. (2009).

The last sustainable agriculture indicator in this category is indigenous knowledge. Current views about indigenous knowledge accept that indigenous knowledge is an important tool which holds promise for agriculture and sustainable development (Abdullah and Hassan, 2015). Fortunately, sample farmers had moderate perception mean score on application of indigenous knowledge for sustainable agriculture in the MA category. This showed that the farmers were eager about applying native knowledge to develop sustainable agricultural production in Mersin. This finding is conflict with that of Thanh et al. (2015).

\subsection{Factors influencing farmers' sustainable agriculture perception}

Table 4 presents the influence of the some variables on the farmers' sustainable agriculture perception. There were 13 independent variables, described in research area and data section, entered in the model, out of which only 4 variables had a statistically significant influence on farmers' perception. The $\mathrm{R}^{2}$ value of model was 0.106 with $\mathrm{F}$ value. This revealed that $10.6 \%$ of variance in the farmers' perception could be explained by these 4 variables.

The most important variable which influence on farmers sustainable agriculture perception was "agricultural programs on TV" with $\beta=0.270$. This means that the sustainable agriculture perception of farmers who watched agricultural program on TV in the past one month much more than farmers who didn't watch. $\beta$ of credit use was -0.122 . The findings revealed that one standard deviation increase in credit use decreases the sustainable agriculture perception by 0.122 standard deviations. This findings tallies with that of Thahn et al. (2015) who reported that agricultural programs on TV positively influenced, but credit used negatively influenced on farmers' sustainable agricultural perception. Besides, "agricultural program on radio" and "cooperative partnership" were another important factors influencing farmers' sustaina-
Table 4 - Results of regression analysis.

\begin{tabular}{|l|c|c|c|c|}
\hline \multicolumn{1}{|c|}{ Variables } & $B$ & Beta & $t$ & Sig. \\
\hline (Constant) & 81.869 & & 61.393 & 0.000 \\
\hline Credit Use & -1.863 & -0.122 & -1.907 & 0.058 \\
\hline $\begin{array}{l}\text { Agricultural } \\
\text { programs } \\
\text { on TV }\end{array}$ & 7.063 & 0.270 & 3.868 & 0.000 \\
\hline $\begin{array}{l}\text { Agricultural } \\
\text { programs } \\
\text { on Radio }\end{array}$ & -6.237 & -0.232 & -3.419 & 0.001 \\
\hline $\begin{array}{l}\text { Cooperative } \\
\text { Partnership }\end{array}$ & -4.521 & -0.159 & -2.396 & 0.017 \\
\hline F $=6.938$ & \multicolumn{5}{|c|}{$\mathrm{R}^{2}=0.106$} \\
\hline
\end{tabular}

ble agriculture perception with $\beta=-0.232$ and $\beta=-0.159$, respectively. For every standard deviation change in "agricultural program on radio" and "cooperative partnership" farmers' sustainable agriculture perception decreases by 0.232 and 0.159 standard deviation, respectively.

\section{Conclusion}

The research results showed that a majority (94.14\%; $n=225)$ of the farmers had favorable perception towards sustainable agriculture in Mersin. In addition, the study showed that farmers highly interested in protecting natural resources for future generations. They concerned about negative effects of agrochemicals on human and animal health. Beside, they had positive perceptions about sustainable agricultural practices such as application of organic fertilizers, application of cover crops, crop rotation and diversification, application of soil tests before applying fertilizers, not burning of plant residues after harvest etc. They were also aware the roles of sustainable agriculture in solving problems of environmental pollution and natural resources degradation, increasing profits and reducing production risks in the long-term; as well as they were aware the importance of selling products by contracts farming. The result of the regression analysis indicated that 4 variables that affecting farmers' sustainable agriculture perception. These variables were agricultural program on $\mathrm{TV}$, agricultural program 
on radio, credit use and cooperative partnership. These variables explained $10.6 \%$ the variation of farmers' sustainable agriculture perception. The Agricultural program on TV was a most significant and positively influence variable on farmers' perception towards sustainable agriculture.

We recommend that efforts to enhance farmers' sustainable agriculture perception in Mersin should be focus on economic benefits and environmentally feasible practices of sustainable agriculture and special programs on sustainable agricultural production should be broadcast more on TV. In addition, the government should encourage and guide farmers with premium and incentive payments to use sustainable agriculture techniques and appropriate inputs. Moreover, the government should take deterrent measures against farmers who using inappropriate and harmful applications such as burning plant residues after harvest, using excessive agricultural chemicals and fertilizers. Finally, it can be said that the study investigated farmers' sustainable agriculture perception, not predict whether farmers will adopt sustainable agriculture practices or whether they did them. Hence, it is necessary that further research should be conducted to find out whether farmers are likely to do so or whether really they did them.

\section{References}

Abdullah A.S., 2014. Minimum tillage and residue management increase soil water content, soil organic matter and canola seed yield and seed oil content in the semiarid areas of Northern Iraq. Soil and Tillage Research, 144: 150-155.

Abdullah H.J. and Hassan T.K., 2015. The use of indigenous knowledge in agriculture and its role in sustainable development. International Journal of Science and Research (IJSR), 4: 1312-1317.

Acar M., Celik I. and Günal H., 2018. Effects of longterm tillage systems on aggregate-associated organic carbon in the eastern Mediterranean region of Turkey. Eurasian J Soil Sci, 7(1): 51-58.

Adeola R.G. and Adetunbi S.I., 2015. Farmers' perception of sustainable agriculture in South-Western Nigeria: Implications for rural economy. International Journal of Applied Agricultural and Apicultural Research, 11: 86-92.
Anonymous, 2011. Mersin tarım master planı, T.C. Mersin Valiliği İl Tarım Müdürlüğü.

Anonymous, 2015. Çukurova Bölge Planı 2014-2023, Çukurova Kalkınma Ajansı, Adana.

Bagheri A., 2010. Potato farmers' perceptions of sustainable agriculture: the case of Ardabil province of Iran. Procedia-Social and Behavioral Sciences, 5: 1977-1981.

Bagheri A., Fami H.S., Rezvanfer A., Asadi A. and Yazdani S., 2008. Perception of paddy farmers towards sustainable agricultural technologies: Case of Haraz Catchments Area in Mazandaran Province of Iran. American Journal of Applied Sciences, 5: 1384-1391.

Brundtland G.H. and Khalid M., 1987. Our common future. New York: Oxford University Press.

Ceyhan V., 2010. Assessing the agricultural sustainability of conventional farming systems in Samsun province of Turkey. African Journal of Agricultural Research, 5: 1572-1583.

Cronbach L.F., 1951. Coefficient alpha and the internal structure of tests. Psychometrika, 16: 297-334.

Gu L. and Anex R.P., 2015. Evaluating cover crops as a climate change adaptation strategy. In $A S A B E$ 1st Climate Change Symposium: Adaptation and Mitigation, Chicago, Illinois, USA.

Guo X.W., Fernando W.G.D. and Entz M., 2005. Effects of crop rotation and tillage on blackleg disease of canola. Canadian Journal of Plant Pathology, 27: 53-57.

Hair F.J., Anderson J.R., Tatham R.Z. and Black W.C., 1994. Multivariate data analysis, 3rd Edition. New York: McMillan Publishing Company.

Kalaycı Ş., 2008. SPSS Uygulamalı Çok Değişkenli Istatistik Teknikleri, Asil Yayın Dağıtım, İstanbul.

Kilic S., Dogan K. and Keskin Gorucu S., 2012. Yanlıș Arazi Kullanımı ve Anız Yakma Sorununa Çözüm Önerileri. TRALLEIS, 1: 36-44.

Migliorini P. and Scaltriti B., 2012. Evaluation of sustainability of the farms in the Agricultural Park of South Milan and their production chain. New Medit, Special Issue: 53-56.

Ministry of Development, 2014. Onuncu Kalkınma Planı (2014 - 2018) Tarım Özel İhtisas Komisyonu Tarım Arazilerinin Sürdürülebilir Kullanımı Çalışma Grubu Raporu, Ankara.

NRCS, 2014. Soil testing: Small scale solutions for your farms, https:/www.nrcs.usda.gov/Internet/ FSE_DOCUMENTS/stelprdb1097094.pdf (Access: 29/01/2018).

Ozcelik A., Turan A. and Tanrıvermis H., 1999. Türkiye'de tarımın pazara entegrasyonunda sözleşmeli tarım ve bu modelin sürdürülebilir kaynak kul- 
lanımı ile üretici geliri üzerine etkileri, Rep. No. 1999-2. Tarım Ekonomisi Araştırma Enstitüsü, Ankara.

Preiti G., Romeo M., Bacchi M. and Monti M., 2017. Soil loss measure from Mediterranean arable cropping systems: Effects of rotation and tillage system on C-factor. Soil and Tillage Research, 170: 85-93.

Rahman S., 2003. Environmental impacts of modern agricultural technology diffusion in Bangladesh: an analysis of farmers' perceptions and their determinants. Journal of Environmental Management, 68: 183-191.

Rahman K.M.A. and Debnath S.C., 2015. Agrochemical use, environmental and health hazards in Bangladesh. International Research Journal of Interdisciplinary \& Multidisciplinary Studies (IRJIMS), 4(1): 75-79.

Sadati A.A., Fami H.S., Asadi A. and Sadati S.A., 2010. Farmer's attitude on sustainable agriculture and its determinants: A case study in Behbahan County of Iran. Research Journal of Applied Sciences, Engineering and Technology, 2: 422-427.

Savci S., 2012. An agricultural pollutant: Chamical fertilizer. International Journal of Environmental Science and Development, 3(1): 77-80.

Shakiru M., 2016. Farmer perceptions and determinants of sustainable agriculture at the farm level: A case study of Musanze. Master, Ondokuz Mayis University, Samsun/Turkey.

Shiri N.Y.S.S. and Nadi H.K., 2013. Study of attitudes towards sustainable agriculture: A case from Iran. International Research of Applied And Basic Sciences, 4: 18005-18012.

Snapp S.S., Swinton S.M., Labarta R., Mutch D., Black J.R., Leep R., Nyiraneza J. and O'Neil K.,
2005. Evaluating cover crops for benefits, cost and performance within cropping system niches. Agronomy Journal, 97: 322-332.

Tanrıverdi K., 2017. Economic analysis of fertilizing based on soil analiysis; Case study on Cumra district in Konya province. Unpublished $\mathrm{PhD}$ Thesis, Selcuk University, Graduate School of Natural and Applied Sciences, Department of Agricultural Economics, Konya.

Tatlıdil F.F., Boz I. and Tatlıdil H., 2009. Farmers' perception on sustainable agriculture and its determinants: a case study in Kahramanmaras province of Turkey. Environ Dev Sustain, 11: 1091-1106.

Terano R., Mohamed Z.A., Shamsudin M.N. and Latif I.A., 2013. Farmers sustainability index: Paddy farmer's farm practices. In 3rd International Conference on Management (3rd ICM 2013) Proceeding, Malaysia.

Thanh N.V., Sukprasert P. and Yapwattanaphun C., 2015. Farmers' sustainable agriculture perception in the Vietnam Uplands: the Case of banana farmers in Quang Tri Province. Research Journal of Applied Sciences, Engineering and Technology, 10: 960-967.

Turhan S., 2005. Tarımda sürdürülebilirlik ve organik tarım. Tarım Ekonomisi Dergisi, 11: 13-24.

Turkish Civil Code, 1983. Çevre Kanunu (Environmental Law), Ankara.

Unver O. and Gamgam H., 2008. Uygulamall temel istatistik yöntemler, Seçkin Yayıncılık, Ankara.

Zhen L., Routray J.K., Zoebisch M.A., Chen G., Xie G. and Cheng S., 2005. Three dimensions of sustainability of farming practices in the North China Plain. A case study from Ningjin County of Shandong Province, PR China. Agriculture, Ecosystems \& Environment, 105: 507-522. 